\section{AATS Online Award Applications}

Now Available at www.aats.org, Deadline July 1, 2012

Second John W. Kirklin Research Scholarship 20132015 provides an opportunity for research, training, and experience for North American surgeons committed to pursuing an academic career in cardiothoracic surgery.

- Research program must be undertaken within the first three years after completion of an approved North American cardiothoracic residency.

- Applications for the scholarship must be submitted during the candidate's first two years in an academic position.

- The scholarship will begin July 1, 2013, and conclude on July 1, 2015.

- The Scholarship provides an annual stipend of $\$ 80,000$ per year paid to the host institution for direct salary support and related research expenses

Deadline: July 1, 2012

Evarts A. Graham Memorial Traveling Fellowship, 2013-2014 grants support for training of international surgeons who have been regarded as having the potential for later international thoracic surgical leadership.

- Candidate must be a non-North American who plans a cardiothoracic surgery training program in a North American center and who has not had extensive (exceeding a total of six months in duration) clinical training in North America prior to submitting an application.

- Candidate should have completed his/her formal training in general surgery and in thoracic and cardiovascular surgery, but should not have reached a senior position.

- The Fellowship provides a stipend of $\$ 75,000$ US, a major portion of which is intended for living and travel expenses incurred when visiting other medical centers

Deadline: July 1, 2012

\section{Heart Valve Summit: Medical, Surgical, and Interventional Decision Making}

October 11-13, 2012

JW Marriott Chicago

Chicago, IL

Program Directors:

David H. Adams, MD, FACC

Steven F. Bolling, MD, FACC

Robert O. Bonow, MD, MACC

Howard C. Herrmann, MD, FACC

Nurse Planner:
Michele Langenfeld, RN, MS

Course Overview:

The American Association for Thoracic Surgery and the American College of Cardiology once again are partnering to bring together CT surgeons and cardiologists in a cooperative, case-based course to address the rapid advances in the treatment of valvular heart disease. With the tradition of interactivity and practical decision making, the unique Heart Valve Summit is designed to engage participants in discussions, debates, and potential controversies surrounding real-world cases using renowned faculty on the cutting edge of the clinically relevant data for valvular heart disease management.

This inter-disciplinary course emphasizes clinical decision making while combining the most relevant medical, surgical and interventional options for patient care. Tools for management are rapidly advancing and can have significant impacts for the entire care team. Breakout sessions for cardiac surgeons, cardiologists, nurses, and physician assistants are designed to involve the specialists in managing their unique challenges from the team perspective.

\section{Target Audience}

This course is intended for cardiothoracic surgeons, cardiologists, interventional cardiologists, internists, nurses, physician assistants, and all health care professionals involved in the evaluation, diagnosis, and/or management of patients with valvular heart disease.

\section{Accreditation}

\section{Physicians}

This course has been approved for AMA PRA Category 1 Credits $^{\mathrm{TM}}$.

\section{Nurses}

The American College of Cardiology Foundation is accredited as a provider of continuing nursing education by the American Nurses Credentialing Center's Commission on Accreditation.

\section{Heart Failure Summit}

21st Century Treatment of Heart Failure: Synchronizing Surgical and Medical Therapies for Better Outcomes

October 18-19, 2012

Intercontinental Hotel \& Bank of America Conference Center Cleveland, $\mathrm{OH}$

The agenda and registration information are available at www.ccfcme.org/heartfailure 12

Program Directors

Katherine J. Hoercher, RN

Nader Moazami, MD

Soon J. Park, MD 